\title{
Rurukan Hajat Golong: an economic model of community resilience in Rancakalong, Sumedang, West Java, Indonesia
}

\author{
Prijana $^{1, *}$, W. Erwina ${ }^{2}$, Samson $^{3}$ \\ ${ }^{1}$ Department of Library Science, Faculty of Communication Science, Padjadjaran University, Indonesia \\ ${ }^{2}$ Department of Library Science, Faculty of Communication Science, Padjadjaran University, Indonesia \\ ${ }^{3}$ Department of Library Science, Faculty of Communication Science, Padjadjaran University, Indonesia \\ *Corresponding author: prijana@gmail.com
}

\begin{abstract}
Knowing the symbolic meanings behind Tradition of Hajat Golong village districts Ciledug Rancakalong Sumedang district, West Java Indonesia. Knowing the role of traditional authorities, which led Rurukan, and explain the relevance Tradition of Hajat Golong the economic resilience of the community. Methods: ethnography. Result: Traditional of Hajat Golong implemented by Rurukan, which is a kind of indigenous communities. Tradition of Hajat Golong executed before entering the 'taun gede', the first rice-planting season. Rurukan had a leader called indigenous stakeholders. Tradition of Hajat Golong is a symbol, preparatory activities of managing farmland and rice production collectively. In carrying out the activities of production, concept of saving and borrowing less desirable communities, they prefer to set aside the harvest to production costs. Conclusion: Tradition ofHajat Golong is a symbol of the resilience of the economy sustainable communities.
\end{abstract}

Keyword: Tradition of Hajat Golong,Rurukan, Pemangku adat, economic resilience, Community

\section{INTRODUCTION}

Rurukan is the designation of the name of indigenous communities. Rurukan HajatGolong is a community farm owner in the village Ciledug Rancakalong districts of Sumedang, West Java Indonesia. Rurukan Hajat Golong have leaders, which locals refer to indigenous stakeholders. Leaders Rurukan selected based lineages have been defined by our ancestors.

Tradition of Hajat Golong implemented before the planting season 'taun gede', the first riceplanting season. The local community is convinced that the first rice-planting will bring an abundant harvest. Therefore during the first rice-planting gives preferential treatment.

Rancakalong society is agrarian society prosper, sufficient food and shelter. Generally, they perceive that welfare can not be measured by numbers of cash income Cash for them is not the only measure to find out that they are prosperous, or less wealthy or poor. They have a unique standard of economic value is realized symbolically. They also live happily, some of them know each other and have a strong emotional bond. Their economic resilience can be measured and observed symbolically. They have a mature economic governance and have the ability to predict of agricultural products.

Data on the economic resilience of the community is actually able to immediately known indigenous stakeholders Rurukan HajatGolong. Traditional authorities as having the ability sampling of communities which are numerous. Samples are set annually almost never misses, meaning representative [1].

The uniqueness increasingly looks seen on the instrument used, the instrument is quite valid. It is said that the instruments used from year to year has not been changed, but the results can be trusted. Tradition of Hajat Golong appeared 
as observation activities. They never use numbers and formulas in using his method. They just use the name of each 'bebekelan' brought in the event Hajat Golong. As the names who attended the event Hajat Golong shows a list of sampling units. While the sample size fluctuates each year, meaning that the numbers go up and down. Agricultural economic actors are not distinguishable from each other, they get treatment and equal footing with each other. Vast farmland not be sized, and not also a consideration in agricultural governance, and income levels are not distinguished from each other. Here, the sampling unit is moving on, that they come at the Tradition of Hajat Golong. Quite rare sampling units come instrument moves on to be observed and measured by the observer (the wife of pemangku adat).

Farmers Rancakalong have a habit in the governance of the crop as follows: 1/3 (one third) of the harvest to the capital, 1/3 (one third) of the crop to be consumed, and 1/3 (one third) more than the harvest for sale. Here, for those who do not own agricultural land, they became a laborer. Here farmhand has a very important role in the governance of harvest, and the local people gave the title Gacong name. Gacong presence as forming the concept of stratification in agricultural governance. Here, those who occupy the top stratification are farmers or farm owner, while occupying the bottom stratification is a farm laborer [2]. For owners of the farm, the crop is a permanent income. As for farm workers, agricultural labor is not a permanent income. Therefore, farm laborers categorized as poor. They are the poor still trying hard to obtain permanent income. The poor seeking permanent income from breeding. N. Gregory Mankiw [3], warns that permanent income is rather difficult to quantify, but it is an important concept. Invented the concept of earnings, economic mobility in a society can be observed, namely the movement of people from one income group to all income groups. Switching group to a higher income could be due to good luck or hard work. Slump to lower income class could be due to bad luck or laziness. Economic mobility can occur on a temporary basis, and some can be more permanent.
In the social literature, the poor man is 2 (two) types as follows: poor transient and permanent poor (structural poverty). Likewise, poverty alleviation how they are different. Tradition of Hajat Golong actually has a purpose achieving economic success farm owner, so that the economic conditions can last from generation to generation.

In the economic literature, discovered the phenomenon of economic mobility as follows: If the father's income of $20 \%$ (twenty percent) higher than the average income of his generation, the children will achieve earnings of $8 \%$ (eight percent) higher than the average income generation. Revenue grandfather noncorrelated significantly with income granddaughter. [4].

Here the focus is on institutional and research community. Institution in question is an informal institution that has been formed and has lasted for generations since the days of their ancestors, which local people call Rurukan. Further community in question is a community that is engaged in agriculture who are in Rancakalong Sumedang, West Java, Indonesia. Institutional Rurukan is still believed and desirable.

\section{METHOD}

Methods: ethnographic study, namely a study that requires fieldwork. The presence of researchers in the field in time sufficient to avoid time-time clock. During its presence in the field, researchers interact in Rurukan tradition in the village Ciledug, and direct observation in various social situations. Also did the collection of documents and hearings with indigenous stakeholders Rurukan, as the primary data source.

Garna [5] said that 'the central aim of ethnography is to understand another way of life from the native point of view, ... ethnography means learning from people' [6]. The main objective is to understand the views ethnographic study of life (way of life), and understand others.

In observation, the researchers conducted a live interview. The study also used informants, name Ado, and information from the informant became an important part in the 
observation. According to the object, the observation made is descriptive observation and observation focused. Descriptive observation, ie observing the social situation and record it into the field-notes. While the focus of observation is observing the social situation as an alloy mindset and actions that have the space and time. Every social situation related to the functioning Rurukan be assessed carefully and understood conceptually.

\section{RESULTS}

Leaders Rurukan follow the lineage, is not selected. Rurukan leaders have the right to manage the farm, and he was obliged to carry out the intent Tradition of hajat golong. Rurukan is a form of informal institutional actors to move the agricultural economy in the village Ciledug. Tradition of Hajat Golong implemented before the 'taun gede'. Leaders Rurukan by local people called Stakeholders customary, and is considered a person skilled in the field of agriculture widely.Tradition of Hajat Golong has five (5) important element in the implementation, which is as follows: 1 / Bebekelan; 2 / Mukadimah; 3 / Tawasulan; 4 / Pangjurug laku; 5 / Ngawangkong.

\section{Bebekelan}

Bebekelan is the proper name of the goods brought citizens in the event Hajat Golong. These items such as food, cake, water and incense. Food and cake brought home to indigenous stakeholders welcome in the kitchen, then placed ngampar in the living room of the house, and covered with a large cloth.

\section{Picture 1. Bebekelan}

Each bebekelan named, and shown to adat wife was waiting in the kitchen, then examined one by one variety of food and pastries (bebekelan) brought residents. Here the diversity and number of bebekelan become an important instrument for measuring readiness before the 'taun gede'. After bebekelan checked and then taken into the middle room house covered with ngampar and cloth laid large. Bebekelan become a symbol of the readiness of the capital costs of agricultural production. The more diverse bebekelan showed high readiness costs. The less diverse bebekelan showed the lack of preparedness of capital costs. Food and cake bebekelan is typical of communities that have the same quality of each other.

Wife indigenous stakeholders have a role to convey the results of his observations and analysis to the traditional authorities as head Rurukan, the economic conditions of the community. The observation and analysis Stakeholder Wife customary to guide preparedness 'taun gede'.

At the beginning of the Mukadimah, Pemangku adatconvey the intent and purpose of implementation of Hajat Golong and convey information about the farm based on economic conditions of citizens. In view of the Pemangku adat, cultivate farmland requires considerable capital cost, if the cost of capital is less enough, then what is to be done. Capital is understood as production costs manages farmland. Indigenous stakeholders have the knowledge and experience in respect of agriculture. In the economic literature it is said that the readiness of the cost of a major determining factor in making a production decision. Hence the decision customary holders is essential in the production process.

If economic conditions weaken citizens before facing 'taun gede', as shown in the lack of diversity bebekelan, then Stakeholders will deliver a custom management principles. For example, the implicit costs increased as much as possible, and discipline in the use of explicit costs. Implicit costs will be borne jointly, work harder, and coordination. The risks faced during the production process, such as the attack of pests, it will be resolved jointly and willing to give time and energy. Pest attacks would be faced together, rolled up like golong.

\section{Mukadimah}

Mukadimah Hajat Golong delivered indigenous stakeholders understood by local people as follows: narekahan tatanen teu keuna ku hama, nya diparancah ku golong, supaya hama diparancah $k u$ katuangan golong' (so that the plant is not attacked by pests, yes expelled only by means of rolled folded like food golong).

Mukadimah contains information that is communicated instructional relating to 
agriculture and way of life. Besides the important information, such as how to cope with that kind of pest miscellaneous, and how penangananya also different from each other.

\section{Tawasulan}

Tawasulan is prayer together in God the Creator, Allah SWT with a main goal Hajat Golong hope come true. The local people looked Tawasulan as 'ngarekeskeun pamaksudan' (set aims and objectives Hajat Golong).

\section{Picture 2. Tawasulan and Bebekelan}

Before Tawasulan performed by each citizen sitting in a circle facing each other. They distributed frankincense and each person holding incense ascertained. Besides the well water in bamboo Kele placed in a forward position. Frankincense and water will serve when it will start working in the fields and rice planting activities. Tawasulan is the man that berketuhanan. Community is a pious society and embrace Islam.

\section{Pangjurug Laku}

Pangjurug laku is the time given to formal leadership, the village head. Formal leadership also provided information and observations of external conditions, and also provide information about government policies are presented to the community in the event Hajat Golong. Pangjurug lakuis a source of information formally representing the government. Pangjurug sold more inclined to provide information about government policies and rural infrastructure. Pangjurug laku is also part Tradition of Hajat Golong. Therefore, each carried Hajat Golong always there Pangjurug laku. Formal leadership also honored, because he has a soul dharma, which is to serve the people.

\section{Ngawangkong}

Ngawangkong is unconference between present in Hajat Golong, they eat together from bebekelan he carried himself. They could talk back information submitted customary holders and Pangjurug laku dialogically. They can discuss among others were present. They exchange ideas about something anything about agriculture. Bebekelan brought voluntary and indigenous stakeholders also provide food and cake specially for the guests present. They do not charge to carry out the intent Golong. They come on its own, not forced to come and bring bebekelan, all is tradition.

Ngawangkong also used as a medium kelangenan among the citizens. Ngawangkong is the final activity of Tradition of Hajat Golong. The entire meal and cake was distributed to anyone who attended the event Hajat Golong. Family atmosphere is felt in Ngawangkong. At the time of Ngawangkong, all the information and plans set out Stakeholders reaffirmed customs until they feel ready to face the taun gede'. After Ngawangkong finished, they pray together and return with water placed in bamboo Kele and carrying incense. It is said that the water in the bamboo Kele believed to be the 'tolak bala'. Water in Kele bamboo placed at the end of the farm, and incense will be lit when the agricultural activity starts. Water in kele bamboo and frankincense understood as a symbol of the spirit of facing 'taun gede'.

\section{DISCUSSION}

Rurukan surviving in Rancakalong is Rurukan Hajat Golong those in the villages Ciledug. Other Rurukan, such as porridge Rurukan Suro (ie traditions to know whether the rice harvest later (forcast) overflow or not), it is less desirable.

It is known that people are ethnic Sundanese Rancakalong which has a view of life that are well conserved. The way they preserve are grown in culture, and established a tradition. Sunda way of life is quite prominent is the ancestral uphold, including the values he has planted, like nyaah ka kolot(Adimihardja, K. [7]). Actual existence Rurukan Hajat Golong to achieve food security and well-being. The interesting thing about Rurukan Hajat Golong is togetherness and gotong royong. Rurukan occupies an enclave and has a homogeneous perspective. They believe that food security can be achieved under the umbrella Rurukan. The importance of further studies on Rurukan Hajat Golong in the Ciledug village, particularly on the management success 
Rurukananalyzed measurable and accountable scientific.

\section{CONCLUDING REMARK}

Hajat Golong implemented Rurukan Ciledug village has managerial significance, which combines elements of economic and cultural. Indigenous stakeholders have the ability to monitor the readiness of capital costs before facing 'taun gede'. Bebekelan brought citizens in Hajat Golong a standard instrument of readiness to face charges 'taun gede'.

Concept of saving and borrowing in the face 'taun gede' less desirable community. They prefer to use the concept of designated crops.

Economic mobilization partially observable, some can notbe observed. Economic mobilization took place not because of the policy, disaster, laziness, or good fortune. Mobilization of the economy moving because of education.

\section{ACKNOWLEDGEMENT}

In this study, prompted by the leadership Rurukan Hajat Golong, name Ado and his wife. It is they who provide information about Rurukan and tradition in the village Ciledug Hajat Golong. They are proud to be leaders and are proud to be Pemangku Rurukan customary. They know a lot about the community Rurukan Hajat Golong and benefits. The important elements in the Tradition of Hajat Golong described by the father of Ado. Here researchers conceptualize the elements in the Tradition of Hajat Golong into five (5) essential elements, namely as follows: Bebekelan, mukadimah, tawasulan, panjurug laku, and ngawangkong.

Sources of research funding obtained from the researchers themselves. Researchers hope to obtain future funding from the sponsor. The study measured more important, for the purpose of explaining in more scientific.

\section{REFERENCES}

1. Prijana \& Semendison. Metode sampling terapan. Bandung, Humaniora; 2005

2. Ritzer, G. Teori Sosiologi. Yogyakarta, Pustaka Pelajar; 2011

3. Mankiw, N. G.. Principles of economics. Jakarta, Erlangga; 2003

4. Mankiw, N. G.. Principles of economics. Jakarta, Erlangga; 2003

5. Garna, J. K. Penelitian Kualitatif, Bandung Pascasarjana Unpad; 1999

6. Prijana. Penelitian etnografi. Bandung: Makalah Seminar Fikom Unpad; 2011

7. Adimihardja, K. Berkarya di belantara budaya. Bandung, Indra prahasta; 2005. 


\section{Picture 1. BEBEKELAN}

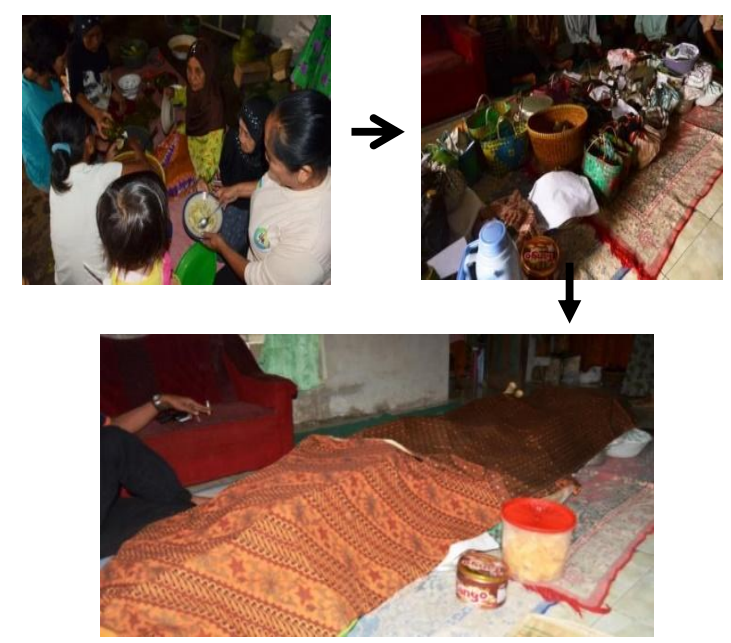

Source: document, 2016

Picture 2. TAWASULAN AND BEBEKELAN
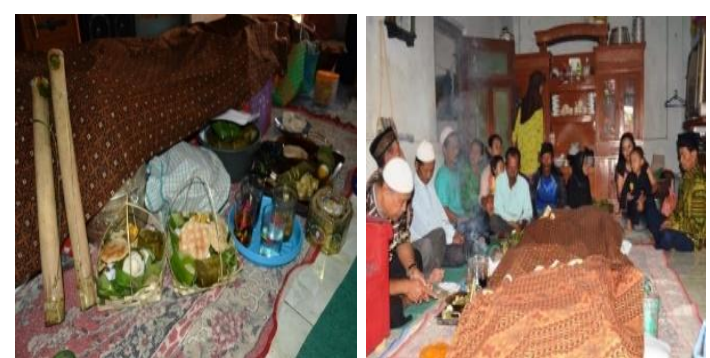

Source: document, 2016 